Research Article

\title{
EFFECT OF DIFFERENT LEVEL OF LEMON EXTRACT ON QUALITY AND SHELF LIFE OF CHICKEN MEATBALLS DURING FROZEN STORAGE
}

\author{
M.N.A. Disha, M.A. Hossain, M.T. Kamal \\ M.M. Rahman and M.A. Hashem* \\ Department of Animal Science, Bangladesh Agricultural University \\ Mymensingh, Bangladesh
}

\begin{abstract}
The aim of the current study was to find out the effect of adding different levels of lemon extract to the chicken meatballs. Fresh lemon extract was incorporated into freshly prepared meatball and compared with $0.01 \%$ beta hydroxyl toluene (BHT) and control (without antioxidant). For this purpose, chicken meatball samples were divided into four treatment groups; viz. $\mathrm{T}_{0}$ (Control), $\mathrm{T}_{1}(0.01 \% \mathrm{BHT}), \mathrm{T}_{2}(0.5 \%$ lemon extract) and $\mathrm{T}_{3}(1 \%$ lemon extract). The study was conducted in completely randomized factorial design. The samples were analyzed for determination of sensory, proximate components, physicochemical, biochemical and microbiological qualities at $0,30^{\text {th }}$ and $90^{\text {th }}$ days of preservation. Color, flavor, Juiciness, tenderness and overall acceptability increased significantly $(p<0.05)$ among different treatment groups than control and BHT group but decreased at different days of intervals. Dry matter (DM) content decreased significantly $(p<0.05)$ with different treatment levels than control and BHT group and increased with days of intervals. Crude protein (CP), ether extract (EE) and Ash of all treatments were decreased significantly $(p<0.05)$ among different treatment groups. Raw $\mathrm{pH}$, cooked $\mathrm{pH}$ and cooking loss were decreased significantly $(p<0.05)$ with different treatment levels than control and BHT group and decreased with days of intervals. Free fatty acid (FFA), peroxide value (POV) and thiobarbituric acid reactive substances (TBARS) value were decreased significantly $(p<0.05)$ with different treatment levels than that of control and BHT group and increased with days of intervals. Total viable count (TVC), total coli form count (TCC) and total yeast mould count (TYMC) decreased significantly $(p<0.05)$ at different treatment levels than that of control and BHT group. Therefore, it can be concluded that $1 \%$ lemon extract for formulation of value-added chicken meatballs was enriched source as natural antioxidant.
\end{abstract}

Keywords: Antioxidant, Frozen storage, Lemon extract, Microbial activity, Chicken meatball

* Corresponding Author: hashem_as@bau.edu.bd 


\section{INTRODUCTION}

Meat is recognized as a highly nutritious food and an excellent source of highquality protein. The essential amino acids in meat are beneficial component of human diet. Fat is an important constituent of human nutrition and contribute to flavor, tenderness, juiciness, appearance, texture and shelf life of meat products (Islam et al., 2018). Thus, the challenge for meat industry is to develop low-fat meat products without compromising sensory and texture characteristics. Low fat meats are a good source of protein and have few calories than non- lean meats which are safe for cardio vascular problem for human being. Low fat meats are popular amongst people following low calorie and low-fat diet. Poultry meat is a good source of selenium, vitamin $\mathrm{B}_{3}, \mathrm{~B}_{6}$ and choline. Selenium has been linked to preventing the free radical activity in the cells and boost immunity. Poultry meat is preferred for consumption over other meats throughout the world, since it is cheap, easily available and has no religious taboos (Prabakaran, 2012). Nowadays, natural antioxidants have increasingly replaced artificial preservatives in food products. In food, reactive oxygen species (ROS) can cause lipid per oxidation, which leads to the deterioration of food. The oxidative deterioration of lipid-containing food is responsible for rancid odors and flavors that can develop during processing and storage; this deterioration decreases nutritional quality and safety of food due to the formation of secondary and potentially toxic compounds such as acetaldehyde, acrolein (2-propenal), butyl hydro peroxide (tertiary) etc. Fatty acids contribute to a wide range of quality attributes for meat like color stability, drip loss and development of oxidative rancidity (Kouba et al., 2003). To prevent autoxidation process, antioxidants have been utilized for many years (Lahucky et al., 2010). Artificial antioxidants like butylated hydroxy anisole (BHA), butylated hydroxy toluene (BHT), and tertiary butyl hydroquinone (TBHQ) have been widely used to preserve meatballs (Fasseas et al., 2007). Using of these antioxidants has been questionable since they have been found to cause toxic, mutagenic and carcinogenic effects in humans and animals (Hayes et al., 2011). Consumers have shifted their interest to natural antioxidants since these are considered safer than synthetic antioxidants. All natural antioxidants, especially of plant source, have greater application potential for consumer's acceptability, palatability, stability, and shelf life of meat products (Jung et al., 2010; Saba et al., 2018). Plant extracts like herbs, spices etc. can change sensory attributes like meat color, within a range not acceptable to the consumers (Karre et al., 2013). It is relevant to poultry meat is prone to color, aroma, and other sensory attributes changes. The positive effect on oxidation as well as negative effect on sensory acceptability of meat addition of natural extract should be well balanced (Magdalena et al., 2017). Results of the study of Keskokoglu and Uren (2017) suggested that addition of grape seed extract (GSE) can be an important factor in decreasing the levels of total heterocyclic aromatic amines (HCAs) in charcoal-barbecued beef meatballs (65\%) and oven 
roasted chicken meatballs (37\%). Lemon extract are being used as an antibacterial potential against diarrhea- causing pathogen. The main content of lemon juice is vitamin $\mathrm{C}$ and citric acid. It is also known to contain bioactive compounds such as phenolics, flavonoids, vitamins, and essential oils which are believed to be responsible for a range of protective benefits including anti-oxidative, antiinflammatory, antitumor, and antimicrobial activities (Karimi et al., 2016). Addition of lemon extract as a natural antioxidant can help to prevent lipid per oxidation process and increase shelf life of foods. Investigation on different levels of lemon extract on chicken meatball has not been carried out yet in Bangladesh. Contini et al. (2014) stated that the surface characteristics of antioxidant active packaging were modified by plasma pretreatment of the PET surface, with some improvement in antioxidant efficacy, and the efficacy of the packaging in delaying oxidative deterioration in cooked meats was retained during storage at ambient temperature. Hence, the study was conducted to examine the addition of lemon extract on sensory, proximate, physicochemical, biochemical, microbiological qualities and recommend value-added chicken meatball enriched with lemon extract and compare its effectiveness as natural antioxidant with a synthetic antioxidant (BHT) in delaying lipid oxidation in chicken meatballs during frozen storage.

\section{MATERIALS AND METHODS}

\section{Materials collection and processing}

Four chickens were slaughtered at Kamal Ranjit (KR) Market, Bangladesh Agricultural University, Mymensingh at $10.00 \mathrm{AM}$. Two and half $\mathrm{kg}$ of boneless chicken meat was collected from slaughtered birds. Meat samples were immediately transferred to the Animal Science Laboratory. All necessary instruments and jars or containers were cleaned with hot water and detergent powder and then dried properly before starting the experimental activities. First chicken meat was properly cleaned with fresh water and fat was trimmed with a sharp knife. Then meat was ground properly and spices, $\mathrm{NaCl}(1.5 \%)$, ice flakes, refined vegetable oil, refined wheat flour, sauce was mixed with grinded meat properly as per experimental design. Meat was divided into four portions, first portion was treated as control $\left(\mathrm{T}_{0}\right)$ and three portions were mixed with $0.01 \%$ BHT $\left(\mathrm{T}_{1}\right), 0.5 \%$ lemon extract $\left(\mathrm{T}_{2}\right)$ and $1 \%$ lemon extract $\left(\mathrm{T}_{3}\right)$. Then meatballs of proper shape were prepared separately. Approximately, the weight of meatball was $40 \mathrm{~g}$. It was then boiled in hot water for 2-3 minute. After that, the water was removed from meatball properly and was fried in hot oil until reddish brown color was obtained. The meatball was stored at $-20^{\circ} \mathrm{C}$ in freeze temperature and aerial packaging was done in zipper bag.

\section{Sensory evaluation}

Different sensory attributes were examined. Each meatball sample was evaluated by a trained 8-member panel. The sensory questionnaires measured intensity on a 5point balanced semantic scale for the attributes viz. color, flavor, tenderness, 
juiciness, and overall acceptability. Eight training sessions were held to familiarize the judges with the attributes to be evaluated and the scale to be used (Rubio et al., 2006). Prior to sample evaluation, all panelists participated in orientation sessions to familiarize with the scale attributes (color, flavor, juiciness, tenderness, overall acceptability) of chicken meatballs using intensity scale. All samples were served in the Petri dishes. Sensory evaluation was accomplished at 0 day and repeated at $30^{\text {th }}$ and $90^{\text {th }}$ days.

\section{Proximate components}

The proximate analysis pertaining to dry matter (DM), ether extract (EE), crude protein (CP) and ash was carried out according to AOAC (1995).

\section{Physicochemical and biochemical properties measurement}

Raw and cooked $\mathrm{pH}$ values of meatballs were measured using $\mathrm{pH}$ meter (Hanna HI99163) and cooking loss was determined using electrical balance. Three biochemical parameters viz. free fatty acid (FFA), Peroxide value (POV), thiobarbituric acid values (TBARS) were analyzed as per the methodology of Sharma et al. (2012).

\section{Microbial assessment}

Microbial assessment was carried out by undertaking total viable count, total coli form count and total yeast-mold count. For microbial assessment, $10 \mathrm{~g}$ of chicken meat sample was aseptically excised from stored stock sample. Each of stored samples was thoroughly and uniformly macerated in a mechanical blender using sterile diluents $(0.1 \%$ peptone water $)$ as per the recommendation of International Organization for Standardization (ISO, 1995). The minced meat sample (10g) was transferred aseptically into a sterile container containing $90 \mathrm{ml}$ of $0.1 \%$ peptone water to make homogenized suspension of 1:10 dilution in a sterile blender. Finally, by using whirly mixture machine different serial dilutions ranging from $10^{-2}$ to $10^{-6}$ were prepared according to the instruction of the standard method (ISO, 1995).

$\mathrm{CFU} / \mathrm{gm}=($ number of colonies $/$ (volume plated $\times$ total dilution $)$

\section{Statistical analysis}

Data were analyzed using SAS Statistical Analysis Software (2002-2003), North Carolina, USA. DMRT test was used to determine the significance of differences among treatments means. The treatment effect, days of interval and interactions between treatment and days of interval was done by factorial experiment.

\section{RESULTS AND DISCUSSION}

\section{Sensory evaluation}

The score range for colors, flavor, tenderness, juiciness and overall acceptability at different treatments were 4.25 to $4.66,3.62$ to $4.44,3.87$ to $4.33,4.00$ to 4.33 and 4.00 to 4.66 , respectively and days of interval for colors, flavor, tenderness, juiciness 
and overall acceptability were 3.50 to $5.00,3.41$ to $4.54,3.50$ to $5.00,3.50$ to 4.90 and 4.00 to 4.54 , respectively (Table 1 ). Color, flavor, tenderness, juiciness and overall acceptability had significantly $(\mathrm{p}<0.05)$ increased with different treatment but storage period had significantly decreased $(p<0.05)$. Siddiqua et al. (2018) found same results except $0.3 \%$ tulsi leaves extract. Sensory evaluation revealed that among different herbs, cardamon was highly preferred in burfi followed by ginger, turmeric, clove, curry leaves and tulsi (Prasad et al., 2017). It was in agreement with the present findings where lemon leaf extract significantly affect at different sensory attributes. Most preferable color was observed from $\mathrm{T}_{3}$ and less preferable color was observed from $\mathrm{T}_{0}$. The most preferable color was observed from 0 day and $30^{\text {th }}$ day and less preferable color from $90^{\text {th }}$ day. Most preferable flavor was observed fromT $\mathrm{T}_{2}$ group and the lowest flavor from $\mathrm{T}_{0}$. Most preferable flavor was observed from 0 day and less preferable from $90^{\text {th }}$ day. So, it was found that the quality was deteriorated with the increase of storage period. Deterioration of flavor during storage occurred due to microbial growth, formation of FFA and oxidative rancidity (Irshad et al., 2016). Most preferable tenderness was observed from $\mathrm{T}_{2}$ and $\mathrm{T}_{3}$ group. Most preferable tenderness was observed at 0 day. When meatballs were frozen, ice crystals form inside the cells of muscle tissue and puncture the cell walls. That's why meatballs leak moisture when they were cooked. Tenderness is interrelated to DM content of meatballs. With the increasing of storage period DM was increased consequently tenderness was decreased with day's intervals. The result of this experiment was related to the findings of Syuhairah et al. (2016). Most preferable juiciness score was observed at $T_{3}$. Most preferable juiciness was observed at 0 day. The results were in accordance with findings of Raja et al. (2014).Turkey meatballs with addition of coriander extract were characterized with highest juiciness compared to control group. Addition of coriander extract there was no negative reactions of the panelists (Magdalena et al., 2017). These finding was in accordance with the present study. Most preferable overall acceptability was observed at $T_{2}$ and $\mathrm{T}_{3}$ group. Most preferable overall acceptability was observed at 0 day. Overall acceptability decreased during storage because of the decline in the sensory score of other parameters like appearance, flavor, and taste. Yadav et al. (2018) reported that overall acceptability decreased significantly during storage period which was similar to the present study. There was found positive and significant interaction between treatment and days of interval for colors, tenderness, juiciness and overall acceptability except flavor (Table 1). 
Table 1. Effect of lemon extract on sensory parameters in chicken meatballs

\begin{tabular}{|c|c|c|c|c|c|c|c|c|c|}
\hline \multirow{2}{*}{ Parameters } & \multirow[b]{2}{*}{ DI } & \multicolumn{4}{|c|}{ Treatments } & \multirow[b]{2}{*}{ Mean } & \multicolumn{3}{|c|}{ Level of significance } \\
\hline & & $\mathrm{T}_{0}$ & $\mathrm{~T}_{1}$ & $\mathrm{~T}_{2}$ & $\mathrm{~T}_{3}$ & & Treat & DI & $\mathrm{T}^{*} \mathrm{DI}$ \\
\hline \multirow{4}{*}{ Color } & 0 & 5.0 & 5.0 & 5.0 & 5.0 & $5.0^{\mathrm{a}}$ & \multirow{4}{*}{$\begin{array}{l}\mathrm{p}< \\
0.01\end{array}$} & \multirow{4}{*}{$\begin{array}{l}\mathrm{p}< \\
0.01\end{array}$} & \multirow{4}{*}{$\begin{array}{l}\mathrm{p}< \\
0.01\end{array}$} \\
\hline & 30 & 5.0 & 5.0 & 5.0 & 5.0 & $5.0^{\mathrm{a}}$ & & & \\
\hline & 90 & 3.0 & 3.0 & 4.0 & 4.0 & $3.5^{\mathrm{b}}$ & & & \\
\hline & Mean & $4.25^{\mathrm{c}}$ & $4.33^{\mathrm{b}}$ & $4.66^{\mathrm{a}}$ & $4.66^{\mathrm{a}}$ & & & & \\
\hline \multirow{4}{*}{ Flavor } & 0 & 4.0 & 4.0 & 5.0 & 5.0 & $4.54^{\mathrm{a}}$ & \multirow{4}{*}{0.032} & \multirow{4}{*}{0.003} & \multirow{4}{*}{0.202} \\
\hline & 30 & 4.0 & 4.0 & $4.66 \pm 0.33$ & $3.33 \pm 0.66$ & $4.0^{\mathrm{b}} \pm 0.24$ & & & \\
\hline & 90 & $3.0 \pm 0.57$ & $3.33 \pm 0.33$ & $3.66 \pm 0.33$ & $4.66 \pm 0.33$ & $3.41^{\mathrm{c}} \pm 0.39$ & & & \\
\hline & Mean & $3.62^{\mathrm{b}} \pm 0.19$ & $3.77^{\mathrm{b}} \pm 0.11$ & $4.44^{\mathrm{a}} \pm 0.22$ & $4.0^{\mathrm{ab}} \pm 0.33$ & & & & \\
\hline \multirow{4}{*}{ Tenderness } & 0 & 5.0 & 5.0 & 5.0 & 5.0 & $5.0^{\mathrm{a}}$ & \multirow{4}{*}{$\begin{array}{l}\mathrm{p}< \\
0.01\end{array}$} & \multirow{4}{*}{$\begin{array}{l}\mathrm{p}< \\
0.01\end{array}$} & \multirow{4}{*}{$\begin{array}{l}\mathrm{p}< \\
0.01\end{array}$} \\
\hline & 30 & 4.0 & 4.0 & 4.0 & 4.0 & $4.0^{\mathrm{b}}$ & & & \\
\hline & 90 & 3.0 & 3.0 & 4.0 & 4.0 & $3.5^{\mathrm{c}}$ & & & \\
\hline & Mean & $3.87^{\mathrm{c}}$ & $4.0^{\mathrm{b}}$ & $4.33^{\mathrm{a}}$ & $4.33^{\mathrm{a}}$ & & & & \\
\hline \multirow{4}{*}{ Juiciness } & 0 & 5.0 & 5.0 & $4.66 \pm 0.33$ & 5.0 & $4.9^{\mathrm{a}} \pm 0.08$ & \multirow{4}{*}{0.165} & \multirow{4}{*}{$\begin{array}{l}\mathrm{p}< \\
0.01\end{array}$} & \multirow{4}{*}{$\begin{array}{l}\mathrm{p}< \\
0.01\end{array}$} \\
\hline & 30 & $4.33 \pm 0.33$ & 4.0 & 4.0 & 4.0 & $4.08^{\mathrm{b}} \pm 0.08$ & & & \\
\hline & 90 & 3.0 & 3.0 & 4.0 & 4.0 & $3.5^{\mathrm{c}}$ & & & \\
\hline & Mean & $4.0^{\mathrm{b}} \pm 0.11$ & $4.0^{\mathrm{b}}$ & $4.22^{\mathrm{ab}} \pm 0.11$ & $4.33^{\mathrm{a}}$ & & & & \\
\hline \multirow{4}{*}{$\begin{array}{l}\text { Overall } \\
\text { acceptability }\end{array}$} & 0 & 4.0 & 4.0 & 5.0 & 5.0 & $4.54^{\mathrm{a}}$ & \multirow{4}{*}{$\begin{array}{l}\mathrm{p}< \\
0.01\end{array}$} & \multirow{4}{*}{$\begin{array}{l}\mathrm{p}< \\
0.01\end{array}$} & \multirow{4}{*}{$\begin{array}{l}\mathrm{p}< \\
0.01\end{array}$} \\
\hline & 30 & 4.0 & 4.0 & 5.0 & 5.0 & $4.50^{\mathrm{b}}$ & & & \\
\hline & 90 & 4.0 & 4.00 & 4.0 & 4.0 & $4.00^{\mathrm{c}}$ & & & \\
\hline & Mean & $4.00^{\mathrm{b}}$ & $4.00^{\mathrm{b}}$ & $4.66^{\mathrm{a}}$ & $4.66^{\mathrm{a}}$ & & & & \\
\hline
\end{tabular}

Sensory scores were 5 for excellent, 4 for very good, 3 for good, 2 for fair, and 1 for poor. Same superscripts in different treatments groups and days of interval did not differ significantly $(\mathrm{p}>0.05)$, whereas different superscripts in different treatments groups and days of interval differ significantly $(\mathrm{p}<0.05) . \mathrm{T}_{0}=$ Control group, $\mathrm{T}_{1}=0.01 \%$ BHT (Beta hydroxyl toluene), $\mathrm{T}_{2}=0.5 \%$ Lemon extract, $\mathrm{T}_{3}=1 \%$ Lemon extract, DI=Days of Intervals, Treat $=$ Treatment, $\mathrm{T} * \mathrm{DI}=$ Interaction of Treatment and Days of Intervals

\section{Proximate analysis}

The range for DM, CP, EE and Ash at different treatment was 49.19 to 53.66, 19.87 to $22.40,8.12$ to 8.60 and 1.12 to 1.68 , respectively and days of interval for DM, CP, EE and ash were 50.21 to $51.10,19.25$ to $20.95,8.28$ to 8.27 and 1.33 to 1.44 , respectively (Table 2). The result showed that all treatment parameters were decreased significantly $(p<0.05)$ but DM increased significantly $(p<0.05)$ than control and BHT group. The present result contracted the earlier findings (Rima et al., 2019; Siddiqua et al., 2018). Most preferable DM content was observed at $\mathrm{T}_{3}$ group. Lowest amount DM content indicates that this product was most preferable. DM content was increased with the increase of storage period because moisture loss was decreased with increasing storage period. Naveena et al. (2008) reported an increase in DM content with increasing storage period for pomegranate peel extract 
and pomegranate rind powder extract, respectively. A decrease in the percentage of DM content was investigated by Santhi and Kalaikannan (2014) in low-fat chicken nuggets with inclusion of oat flour. Most preferable $\mathrm{CP}$ was observed at $\mathrm{T}_{0}$ group. $\mathrm{CP}$ content was decreased with the increasing storage period. Most preferable $\mathrm{CP}$ content was observed at 0 day. Suradkar et al. (2013) reported a decrease in the protein content of chicken nuggets containing bread crumbs. Protein content decreased significantly in wheat bran (WB) and dried carrot pomace (DCP) incorporated with chicken sausage (Yadav et al., 2018), which was similar to the present study. Jahan et al. (2018) did not found same trend with pomegranate extract beef meatball. Most preferable EE content was observed from $\mathrm{T}_{3}$ group. Lowest amount of EE content indicates this product is most preferable for consumers' health. EE content was decreased with increasing storage period which was similar to Jahan et al. (2018). Data shows that EE content was decreased to $8.28 \%$ in all treatments after 90 days of storage. Verma et al. (2013) observed a decrease in fat content of mutton nuggets by incorporation of guava powder. EE content of the products showed significantly $(\mathrm{p}<0.05)$ decreasing trend with increasing levels of incorporation of pumpkin in chicken sausages reported by Zargar et al. (2014). Most preferable ash content was observed from $\mathrm{T}_{3}$ group. Lowest amount of ash content indicates this product is most preferable for consumers' health. Ash content was significantly $(\mathrm{p}<0.05)$ increased with increasing storage period. Most preferable ash content was observed at 0 day. The data showed that highest amount of ash content was increased to $1.44 \%$ in all treatments after 90 days of storage. Zargar et al. (2017) reported that ash content of the products showed significant $(\mathrm{P}<0.05)$ decreasing trend with increasing levels of incorporation of carrot in chicken sausages. There was positive and significant interaction between treatment and days of interval for DM, CP, EE and Ash (Table 2). 
Table 2. Effect of lemon extract on proximate components in chicken meatballs

\begin{tabular}{|c|c|c|c|c|c|c|c|c|c|}
\hline \multirow{2}{*}{ Parameters } & \multirow{2}{*}{ DI } & \multicolumn{4}{|c|}{ Treatments } & \multirow{2}{*}{ Mean } & \multicolumn{3}{|c|}{ Level of significance } \\
\hline & & $\mathrm{T}_{0}$ & $\mathrm{~T}_{1}$ & $\mathrm{~T}_{2}$ & $\mathrm{~T}_{3}$ & & Treat. & DI & $\mathrm{T} * \mathrm{DI}$ \\
\hline \multirow{4}{*}{$\mathrm{DM}(\%)$} & 0 & $52.63 \pm 0.03$ & $53.69 \pm 0.01$ & $47.71 \pm 0.03$ & $47.98 \pm 0.04$ & $50.21^{\mathrm{c}} \pm 0.02$ & \multirow{4}{*}{$\mathrm{p}<0.001$} & \multirow{4}{*}{$\mathrm{p}<0.001$} & \multirow{4}{*}{$\mathrm{p}<0.001$} \\
\hline & 30 & $55.00 \pm 0.01$ & $51.55 \pm 0.06$ & $47.49 \pm 0.07$ & $50.36 \pm 0.14$ & $51.10^{\mathrm{b}} \pm 0.07$ & & & \\
\hline & 90 & $53.34 \pm 0.01$ & $51.30 \pm 0.05$ & $55.66 \pm 0.01$ & $49.24 \pm 0.05$ & $52.38^{\mathrm{a}} \pm 0.03$ & & & \\
\hline & Mean & $53.66^{\mathrm{a}} \pm 0.01$ & $51.99^{\mathrm{b}} \pm 0.04$ & $50.29^{c} \pm 0.03$ & $49.19^{\mathrm{d}} \pm 0.07$ & & & & \\
\hline \multirow{4}{*}{$\mathrm{CP}(\%)$} & 0 & $22.61 \pm 0.01$ & $21.20 \pm 0.05$ & $20.37 \pm 0.03$ & $19.72 \pm 0.01$ & $20.95^{\mathrm{a}} \pm 0.02$ & \multirow{4}{*}{$\mathrm{p}<0.001$} & \multirow{4}{*}{$\mathrm{p}<0.001$} & \multirow{4}{*}{$\mathrm{p}<0.001$} \\
\hline & 30 & $21.84 \pm 0.01$ & $21.37 \pm 0.01$ & $20.37 \pm 0.03$ & $19.65 \pm 0.02$ & $20.81^{\mathrm{b}} \pm 0.01$ & & & \\
\hline & 90 & $22.75 \pm 0.03$ & $21.28 \pm 0.03$ & $20.27 \pm 0.01$ & $20.25 \pm 0.02$ & $19.25^{\mathrm{c}} \pm 0.02$ & & & \\
\hline & Mean & $22.40^{\mathrm{a}} \pm 0.13$ & $21.28^{\mathrm{b}} \pm 0.03$ & $20.39^{c} \pm 0.02$ & $19.87^{\mathrm{d}} \pm 0.01$ & & & & \\
\hline \multirow{4}{*}{$\mathrm{EE}(\%)$} & 0 & $8.58 \pm 0.02$ & $8.63 \pm 0.02$ & $8.58 \pm 0.02$ & $7.67 \pm 0.07$ & $8.47^{\mathrm{a}} \pm 0.07$ & \multirow{4}{*}{$\mathrm{p}<0.001$} & \multirow{4}{*}{$\mathrm{p}<0.001$} & \multirow{4}{*}{$\mathrm{p}<0.001$} \\
\hline & 30 & $8.71 \pm 0.01$ & $8.44 \pm 0.03$ & $8.71 \pm 0.01$ & $8.20 \pm 0.01$ & $8.42^{\mathrm{b}} \pm 0.01$ & & & \\
\hline & 90 & $8.52 \pm 0.01$ & $8.33 \pm 0.01$ & $8.52 \pm 0.01$ & $8.29 \pm 0.01$ & $8.28^{\mathrm{c}} \pm 0.01$ & & & \\
\hline & Mean & $8.60^{\mathrm{a}} \pm 0.01$ & $8.46^{\mathrm{b}} \pm 0.02$ & $8.33^{\mathrm{c}} \pm 0.03$ & $8.12^{\mathrm{d}} \pm 0.03$ & & & & \\
\hline \multirow{4}{*}{ Ash $(\%)$} & 0 & $1.72 \pm 0.01$ & $1.61 \pm 0.03$ & $1.14 \pm 0.01$ & $1.16 \pm 0.01$ & $1.33^{\mathrm{c}} \pm 0.01$ & \multirow{4}{*}{$\mathrm{p}<0.001$} & \multirow{4}{*}{$\mathrm{p}<0.001$} & \multirow{4}{*}{$\mathrm{p}<0.001$} \\
\hline & 30 & $1.62 \pm 0.03$ & $1.42 \pm 0.01$ & $1.20 \pm 0.01$ & $1.07 \pm 0.03$ & $1.43^{\mathrm{b}} \pm 0.02$ & & & \\
\hline & 90 & $1.69 \pm 0.01$ & $1.53 \pm 0.01$ & $1.41 \pm 0.01$ & $1.12 \pm 0.01$ & $1.44^{\mathrm{a}} \pm 0.01$ & & & \\
\hline & Mean & $1.68^{\mathrm{a}} \pm 0.01$ & $1.52^{\mathrm{b}} \pm 0.01$ & $1.26^{\mathrm{c}} \pm .01$ & $1.12^{\mathrm{d}} \pm 0.01$ & & & & \\
\hline
\end{tabular}

Different superscripts in different treatments groups and days of interval differ significantly $(\mathrm{p}<0.05), \mathrm{T} 0=\mathrm{Control}$ group, $\mathrm{T}_{1}=0.01 \%$ BHT (Beta hydroxyl toluene), $\mathrm{T}_{2}=0.5 \%$ Lemon extract, $\mathrm{T}_{3}=1 \%$ Lemon extract, DI=Days of Intervals, Treat $=$ Treatment, $\mathrm{T} * \mathrm{DI}=$ Interaction of Treatment and Days of Interval. 


\section{Physicochemical properties}

The range for raw $\mathrm{pH}$, cooked $\mathrm{pH}$ and cooking loss at different treatments were 5.64 to $5.81,5.98$ to 6.05 and 23.52to 27.40 , respectively. The range values for days of interval for raw $\mathrm{pH}$, cooked $\mathrm{pH}$ and cooking loss were 5.64 to 5.87, 5.99 to 6.05 and 25.54 to 26.87, respectively (Table 3 ). Cooked $\mathrm{pH}$, cooking loss at different treatments was significantly $(\mathrm{P}<.05)$ increased but raw $\mathrm{pH}$ was significantly $(\mathrm{P}<0.05)$ decreased. The self-life of raw $\mathrm{pH}$, cooked $\mathrm{pH}$ and cooking loss was significantly decreased $(\mathrm{P}<0.05)$ with storage period. Data showed a slight decrease in raw $\mathrm{pH}$ values for all treatments and an increase in the acidity values for all samples along with storage time during 90 days of storage as a result of increasing of FFAs due to rancidity. Most preferable raw $\mathrm{pH}$ was observed from control group. Highest amount of raw $\mathrm{pH}$ indicates this product is most preferable for consumers' health. Similar decreasing trend in $\mathrm{pH}$ was reported by Verma et al. (2013) in mutton nuggets incorporated with guava powder and Banerjee et al. (2012) in goat meat nuggets incorporated with broccoli powder extract. Bacteria and mold have a tendency to increase with increasing storage time, and they secrete components that affect increasing raw $\mathrm{pH}$. Data shows a slight increase in cooked $\mathrm{pH}$ values and a decrease in acidity values for all samples along with addition of synthetic antioxidant and natural antioxidants as a result of decreasing of fatty acids due to lower rancidity. Most preferable cooked $\mathrm{pH}$ was observed from $\mathrm{T}_{2}$ and $\mathrm{T}_{3}$ groups. Highest amount of cooked $\mathrm{pH}$ indicates this product is most preferable for consumers' health. Data showed a slight decrease in cooked $\mathrm{pH}$ values for all treatments and an increase in acidity values for all samples along with storage time during 90 days of storage as a result of increasing of FFAs due to rancidity. Most preferable cooking loss was observed at $\mathrm{T}_{3}$ group. Lowest amount of cooking loss indicates this product is most preferable for consumers' choices. Cooking loss refers to the reduction in weight of meatballs during cooking process (Jama et al., 2008) showed the similar trend with the present experiment. Major components of cooking losses are thawing, dripping and evaporation. Such losses are lower following a rapid freezing compared with slow freezing. Drip loss is the loss of fluid from meatballs and water evaporation from the shrinkage of muscle proteins (actin and myosin) (Yu et al., 2005). There was positive and significant interaction between treatment and days of interval for raw $\mathrm{pH}$, cooked $\mathrm{pH}$ and cooking loss (Table 3). 
Table 3. Effect of lemon extract on physicochemical properties in chicken meatballs

\begin{tabular}{|c|c|c|c|c|c|c|c|c|c|}
\hline \multirow{2}{*}{ Parameters } & \multirow{2}{*}{ DI } & \multicolumn{4}{|c|}{ Treatments } & \multirow{2}{*}{ Mean } & \multicolumn{3}{|c|}{ Level of significance } \\
\hline & & $\mathrm{T}_{0}$ & $\mathrm{~T}_{1}$ & $\mathrm{~T}_{2}$ & $\mathrm{~T}_{3}$ & & Treat. & DI & $\mathrm{T} * \mathrm{DI}$ \\
\hline \multirow{4}{*}{ Raw pH } & 0 & $5.92 \pm 0.01$ & $5.89 \pm 0.02$ & $5.88 \pm 0.01$ & $5.80 \pm 0.02$ & $5.87^{\mathrm{a}} \pm 0.01$ & \multirow{4}{*}{$\begin{array}{c}\mathrm{p}<0.00 \\
1\end{array}$} & \multirow{4}{*}{$\begin{array}{c}\mathrm{p}<0.00 \\
1\end{array}$} & \multirow{4}{*}{$\begin{array}{c}\mathrm{p}<0.00 \\
1\end{array}$} \\
\hline & 30 & $5.70 \pm 0.01$ & $5.87 \pm 0.01$ & $5.86 \pm 0.02$ & $5.56 \pm 0.01$ & $5.75^{\mathrm{b}} \pm 0.01$ & & & \\
\hline & 90 & $5.86 \pm 0.03$ & $5.65 \pm 0.03$ & $5.51 \pm 0.05$ & $5.56 \pm 0.01$ & $5.64^{c} \pm 0.03$ & & & \\
\hline & $\begin{array}{c}\text { Mea } \\
\mathrm{n}\end{array}$ & $5.81^{\mathrm{a}} \pm 0.01$ & $5.80^{\mathrm{a}} \pm .02$ & $5.75^{\mathrm{b}} \pm 0.02$ & $5.64^{\mathrm{c}} \pm 0.03$ & & & & \\
\hline \multirow{4}{*}{ Cooked pH } & 0 & $6.05 \pm 0.01$ & $6.05 \pm 0.01$ & $6.04 \pm 0.01$ & $6.05 \pm 0.01$ & $6.05^{\mathrm{a}} \pm 0.01$ & \multirow{4}{*}{$\begin{array}{c}\mathrm{p}<0.00 \\
1\end{array}$} & \multirow{4}{*}{$\begin{array}{c}\mathrm{p}<0.00 \\
1\end{array}$} & \multirow{4}{*}{$\begin{array}{c}\mathrm{p}<0.00 \\
1\end{array}$} \\
\hline & 30 & $6.04 \pm 0.01$ & $6.02 \pm 0.01$ & $6.10 \pm 0.02$ & $6.03 \pm 0.02$ & $6.05^{\mathrm{a}} \pm 0.01$ & & & \\
\hline & 90 & $5.86 \pm 0.01$ & $6.06 \pm 0.01$ & $6.01 \pm 0.02$ & $6.06 \pm 0.01$ & $5.99^{\mathrm{b}} \pm 0.01$ & & & \\
\hline & $\begin{array}{c}\text { Mea } \\
\mathrm{n}\end{array}$ & $5.98^{\mathrm{b}} \pm .01$ & $6.04^{\mathrm{a}} \pm 0.01$ & $6.05^{\mathrm{a}} \pm 0.02$ & $6.05^{\mathrm{a}} \pm 0.01$ & & & & \\
\hline \multirow{4}{*}{$\begin{array}{c}\text { Cooking loss } \\
(\%)\end{array}$} & 0 & $\begin{array}{c}28.02 \pm 0.0 \\
1\end{array}$ & $\begin{array}{c}27.19 \pm 0.0 \\
1\end{array}$ & $\begin{array}{c}26.32 \pm 0.0 \\
2\end{array}$ & $\begin{array}{c}26.04 \pm 0.0 \\
2\end{array}$ & $\begin{array}{c}26.87^{\mathrm{a}} \pm 0.0 \\
1\end{array}$ & \multirow{4}{*}{$\begin{array}{c}\mathrm{p}<0.00 \\
1\end{array}$} & \multirow{4}{*}{$\begin{array}{c}\mathrm{p}<0.00 \\
1\end{array}$} & \multirow{4}{*}{$\begin{array}{c}\mathrm{p}<0.00 \\
1\end{array}$} \\
\hline & 30 & $\begin{array}{c}27.02 \pm 0.0 \\
1\end{array}$ & $\begin{array}{c}28.15 \pm 0.0 \\
3\end{array}$ & $\begin{array}{c}27.05 \pm 0.0 \\
1\end{array}$ & $\begin{array}{c}22.03 \pm 0.0 \\
1\end{array}$ & $26.06^{\mathrm{b}} \pm 0.0$ & & & \\
\hline & 90 & $\begin{array}{c}27.17 \pm 0.0 \\
1\end{array}$ & $\begin{array}{c}26.43 \pm 0.0 \\
3\end{array}$ & $\begin{array}{c}26.09 \pm 0.0 \\
1\end{array}$ & $\begin{array}{c}22.49 \pm 0.0 \\
6\end{array}$ & $\begin{array}{c}25.54^{\mathrm{c}} \pm 0.0 \\
2\end{array}$ & & & \\
\hline & $\begin{array}{c}\text { Mea } \\
\mathrm{n}\end{array}$ & $\begin{array}{c}27.40^{\mathrm{a}} \pm 0.0 \\
1\end{array}$ & $\begin{array}{c}27.26^{\mathrm{b}} \pm 0.0 \\
2\end{array}$ & $\begin{array}{c}26.49^{c} \pm 0.0 \\
1\end{array}$ & $\begin{array}{c}23.52^{\mathrm{d}} \pm 0.0 \\
3\end{array}$ & & & & \\
\hline
\end{tabular}

Same superscripts in different treatments groups and days of interval did not differ significantly ( $>0.05)$, whereas different superscripts in different treatments groups and days of interval differ significantly $(\mathrm{p}<0.05)$. T0= Control group, $\mathrm{T}_{1}=0.01 \%$ BHT $(\mathrm{Beta}$ hydroxyl toluene), $\mathrm{T}_{2}=0.5 \%$ Lemon extract, $\mathrm{T}_{3}=1 \%$ Lemon extract, $\mathrm{DI}=$ Days of Intervals, Treat= Treatment, $\mathrm{T} * \mathrm{DI}=\mathrm{Interaction}$ of Treatment and Days of Intervals. 


\section{Biochemical properties}

The ranges for FFA, POV and TBARS at different treatment were 0.30 to $0.38,2.76$ to 4.16 and 0.11 to 0.1 , respectively and for days of interval FFA, POV and TBARS were 0.32 to $0.35,2.95$ to 3.26 and 0.11 to 0.14 , respectively (Table 4). FFA, POV and TBRAS of all treatment decreased significantly $(\mathrm{p}<0.05)$ but for days of interval increased significantly $(\mathrm{p}<0.05)$. Most preferable FFA value was observed at 0 day and less was observed at $90^{\text {th }}$ day. Most preferable FFA value was observed at $T_{3}$ group. The treated sample had lower content of FFA as compared to control group, which might be due to the antioxidant properties in lemon extract in treated group. With increasing storage period, a significant rise in FFAs was reported by Baker et al. $(2013)$ which was similar to the present study. The significant $(p<0.05)$ increase in FFA content of the products during storage might be due to growth of lipolytic microorganisms (Das et al., 2008). FFAs are products of enzymatic/ microbial degradation of lipids. It gives information about stability of fat during storage. Most preferable POV was observed at $\mathrm{T}_{3}$ group. Lowest amount peroxide value indicates this product is most preferable for consumers' health. During storage, POV increased in all treatments. However, antioxidant with treatments generally could minimize POV in food sample during storage compared with the control. Lund et al. (2007) reported on POV in sausage with three treatments (rosemary extract, collagen fiber preparation impregnated with rosemary extract and collagen hydrolyses impregnated with rosemary extract); samples with three treatments showed lower values than $T_{0}$. Most preferable TBARS value was observed from $T_{3}$. Lowest amount of TBARS value indicates the product is most preferable for consumers' health. TBARS values increased significantly $(\mathrm{p}<0.05)$ during refrigerated storage period. Similar findings were reported by Chidanandaiah et al. (2009) in meat patties during refrigerated storage period. Yadav et al. (2018) found a significant increase in TBARS value of control and fiber enriched sausage with an increase in storage period. There was positive and significant interaction between treatment and days of interval for FFA, POV and TBARS (Table 4). 
Table 4. Effect of lemon extract on biochemical parameters in chicken meatballs

\begin{tabular}{|c|c|c|c|c|c|c|c|c|c|}
\hline \multirow{2}{*}{ Parameters } & \multirow{2}{*}{ DI } & \multicolumn{4}{|c|}{ Treatments } & \multirow{2}{*}{ Mean } & \multicolumn{3}{|c|}{ Level of significance } \\
\hline & & $\mathrm{T}_{0}$ & $\mathrm{~T}_{1}$ & $\mathrm{~T}_{2}$ & $\mathrm{~T}_{3}$ & & Treat. & DI & $\mathrm{T} * \mathrm{DI}$ \\
\hline \multirow{4}{*}{ FFA $(\%)$} & 0 & $0.36 \pm 0.01$ & $0.32 \pm 0.01$ & $0.31 \pm 0.02$ & $0.31 \pm 0.01$ & $0.32^{\mathrm{c}} \pm 0.01$ & \multirow{4}{*}{$\mathrm{p}<0.001$} & \multirow{4}{*}{$\mathrm{p}<0.001$} & \multirow{4}{*}{$\mathrm{p}<0.001$} \\
\hline & 30 & $0.38 \pm 0.01$ & $0.33 \pm 0.02$ & $0.33 \pm 0.02$ & $0.30 \pm 0.01$ & $0.33^{c} \pm 0.02$ & & & \\
\hline & 90 & $0.42 \pm 0.01$ & $0.34 \pm 0.01$ & $0.33 \pm 0.01$ & $0.31 \pm 0.01$ & $0.35^{\mathrm{a}} \pm 0.01$ & & & \\
\hline & Mean & $0.38^{\mathrm{a}} \pm 0.01$ & $0.33^{\mathrm{b}} \pm 0.01$ & $0.32^{\mathrm{b}} \pm 0.01$ & $0.30^{\mathrm{c}} \pm 0.01$ & & & & \\
\hline \multirow{4}{*}{ POV (meq/kg) } & 0 & $3.86 \pm 0.06$ & $3.87 \pm 0.02$ & $2.86 \pm 0.02$ & $2.90 \pm 0.01$ & $3.17^{\mathrm{a}} \pm 0.02$ & \multirow{4}{*}{$\mathrm{p}<0.001$} & \multirow{4}{*}{$\mathrm{p}<0.001$} & \multirow{4}{*}{$\mathrm{p}<0.001$} \\
\hline & 30 & $4.01 \pm 0.02$ & $3.72 \pm 0.01$ & $2.78 \pm 0.01$ & $2.53 \pm 0.02$ & $3.26^{\mathrm{c}} \pm 0.01$ & & & \\
\hline & 90 & $4.62 \pm 0.04$ & $3.91 \pm 0.01$ & $2.67 \pm 0.02$ & $2.85 \pm 0.01$ & $3.51^{\mathrm{c}} \pm 0.02$ & & & \\
\hline & Mean & $4.16^{\mathrm{a}} \pm 0.04$ & $3.83^{\mathrm{b}} \pm 0.01$ & $2.77^{\mathrm{c}} \pm 0.01$ & $2.76^{\mathrm{c}} \pm 0.01$ & & & & \\
\hline \multirow{4}{*}{ TBARS (mg-MA/kg) } & 0 & $0.13 \pm 0.02$ & $0.11 \pm 0.01$ & $0.08 \pm 0.03$ & $0.11 \pm 0.03$ & $0.11^{\mathrm{c}} \pm 0.02$ & \multirow{4}{*}{$\mathrm{p}<0.001$} & \multirow{4}{*}{$\mathrm{p}<0.001$} & \multirow{4}{*}{$\mathrm{p}<0.001$} \\
\hline & 30 & $0.15 \pm 0.01$ & $0.13 \pm 0.01$ & $0.11 \pm 0.01$ & $0.11 \pm 0.03$ & $0.12^{\mathrm{b}} \pm 0.01$ & & & \\
\hline & 90 & $0.22 \pm 0.02$ & $0.12 \pm 0.01$ & $0.12 \pm 0.01$ & $0.12 \pm 0.01$ & $0.14^{\mathrm{a}} \pm 0.01$ & & & \\
\hline & Mean & $0.17^{\mathrm{a}} \pm 0.01$ & $0.12^{\mathrm{b}} \pm 0.01$ & $0.10^{c} \pm 0.01$ & $0.11^{\mathrm{c}} \pm 0.02$ & & & & \\
\hline
\end{tabular}

Same superscripts in different treatments groups and days of interval did not differ significantly $(\mathrm{p}>0.05)$, whereas different superscripts in different treatments groups and days of interval differ significantly $(\mathrm{p}<0.05)$. $\mathrm{T}_{0}=$ Control group, $\mathrm{T}_{1}=0.01 \%$ BHT $(\mathrm{Beta}$ hydroxyl toluene), $\mathrm{T}_{2}=0.5 \%$ Lemon extract, $\mathrm{T}_{3}=1 \%$ Lemon extract, $\mathrm{DI}=$ Days of Intervals, Treat= Treatment, $\mathrm{T} * \mathrm{DI}=\mathrm{Interaction}$ of Treatment and Days of Intervals. 


\section{Microbiological assessment}

The ranges for TVC, TCC and TYMC at different treatment were 6.17 to $6.54,1.11$ to 1.41 and 1.40 to 1.69 , respectively and for days of interval TVC, TCC and TYMC were 6.22 to $6.4,1.24$ to 1.31 and 1.37 to 1.86 , respectively (Table 5). TVC in the $\mathrm{T}_{0}$ group (6.54 $\operatorname{logs} \mathrm{CFU} / \mathrm{g})$ was significantly $(\mathrm{p}<0.005)$ higher than the treated samples. Less amount of TVC value indicates this product is most preferable for consumers' health ( $\mathrm{T}_{3}$ group). The amount of TVC was increased with increasing storage period. The antioxidant compounds blocked the deteriorating of fat and helped to prevent the metabolism of fat by bacteria. As a result, bacterial growth was lower in chicken meatballs treated with antioxidants. It was reported by Babatunde and Adewumi (2015) that plant extracts like garlic, ginger and roselle provided antioxidant and antimicrobial benefits to raw chicken patties during cold storage. Microbial load was reduced in treated samples than $\mathrm{T}_{0}$. TCC in the control sample $(1.41 \log \mathrm{CFU} / \mathrm{g})$ was significantly $(\mathrm{p}<0.05)$ higher than treated samples. Less amount of TCC value indicates the product is most preferable for consumers' health. During storage, TCC value was decreased. Similar findings were observed by Singh and Immanuel (2014) of raw chicken meat emulsion incorporated with clove powder, ginger and garlic paste at refrigerated storage $\left(4 \pm 1^{\circ} \mathrm{C}\right)$. Reddy et al. (2017) observed a significantly $(\mathrm{P}<0.05)$ lower TCC in chicken meat patties incorporated with natural antioxidant extracts i.e., rosemary (RE) and green tea (GTE). TYMC count in the $\mathrm{T}_{0}$ $(1.69 \log \mathrm{CFU} / \mathrm{g})$ was significantly $(\mathrm{p}<0.05))$ higher than treated group. Less amount of TYMC value indicates the product is most preferable for consumers' health. Highest TYMC was found at 0 day and minimum at 90 days. There was positive and significant interaction between treatment and days of interval for TVC, TCC and TYMC (Table 5). 
Table 5. Effect of lemon extract on different microbe's population in chicken meatballs

\begin{tabular}{|c|c|c|c|c|c|c|c|c|c|}
\hline \multirow{2}{*}{ Parameters } & \multirow{2}{*}{ DI } & \multicolumn{4}{|c|}{ Treatments } & \multirow{2}{*}{ Mean } & \multicolumn{3}{|c|}{ Level of significance } \\
\hline & & $\mathrm{T}_{0}$ & $\mathrm{~T}_{1}$ & $\mathrm{~T}_{2}$ & $\mathrm{~T}_{3}$ & & Treat. & DI & $\mathrm{T} * \mathrm{DI}$ \\
\hline \multirow{4}{*}{ TVC (logCFU/g) } & 0 & $6.22 \pm 0.02$ & $6.15 \pm 0.05$ & $6.21 \pm 0.01$ & $6.21 \pm 0.01$ & $6.19^{\mathrm{b}} \pm 0.02$ & \multirow{4}{*}{$\mathrm{p}<0.001$} & \multirow{4}{*}{$\mathrm{p}<0.001$} & \multirow{4}{*}{$\mathrm{p}<0.001$} \\
\hline & 30 & $6.53 \pm 0.03$ & $6.31 \pm 0.03$ & $6.12 \pm 0.04$ & $6.12 \pm 0.04$ & $6.25^{\mathrm{b}} \pm 0.03$ & & & \\
\hline & 90 & $6.78 \pm 0.01$ & $6.27 \pm 0.01$ & $6.19 \pm 0.03$ & $6.19 \pm 0.03$ & $6.35^{\mathrm{a}} \pm 0.01$ & & & \\
\hline & Mean & $6.54^{\mathrm{a}} \pm 0.02$ & $6.24^{\mathrm{b}} \pm 0.03$ & $6.17^{\mathrm{c}} \pm 0.02$ & $6.17^{\mathrm{d}} \pm 0.02$ & & & & \\
\hline \multirow{4}{*}{ TCC (logCFU/g) } & 0 & $1.44 \pm 0.02$ & $1.32 \pm 0.01$ & $1.38 \pm 0.03$ & $1.15 \pm 0.04$ & $1.31^{\mathrm{a}} \pm 0.05$ & \multirow{4}{*}{$\mathrm{p}<0.001$} & \multirow{4}{*}{$\mathrm{p}<0.001$} & \multirow{4}{*}{$\mathrm{p}<0.001$} \\
\hline & 30 & $1.36 \pm 0.01$ & $1.33 \pm 0.01$ & $1.26 \pm 0.01$ & $1.07 \pm 0.01$ & $1.25^{\mathrm{b}} \pm 0.02$ & & & \\
\hline & 90 & $1.45 \pm 0.01$ & $1.39 \pm 0.01$ & $1.02 \pm 0.03$ & $1.11 \pm 0.01$ & $1.24^{\mathrm{b}} \pm 0.01$ & & & \\
\hline & Mean & $1.41^{\mathrm{a}} \pm 0.01$ & $1.34^{\mathrm{b}} \pm 0.01$ & $1.22^{\mathrm{c}} \pm 0.02$ & $1.11^{\mathrm{d}} \pm 0.02$ & & & & \\
\hline \multirow{4}{*}{ TYMC $(\log C F U / g)$} & 0 & $1.90 \pm 0.01$ & $1.89 \pm 0.01$ & $1.82 \pm 0.04$ & $1.85 \pm 0.01$ & $1.86^{\mathrm{a}} \pm 0.01$ & \multirow{4}{*}{$\mathrm{p}<0.001$} & \multirow{4}{*}{$\mathrm{p}<0.001$} & \multirow{4}{*}{$\mathrm{p}<0.001$} \\
\hline & 30 & $1.67 \pm 0.01$ & $1.51 \pm 0.01$ & $1.43 \pm 0.02$ & $1.34 \pm 0.01$ & $1.49^{\mathrm{b}} \pm 0.01$ & & & \\
\hline & 90 & $1.57 \pm 0.03$ & $1.40 \pm 0.03$ & $1.51 \pm 0.01$ & $1.01 \pm 0.01$ & $1.37^{\mathrm{c}} \pm 0.02$ & & & \\
\hline & Mean & $1.69^{\mathrm{a}} \pm 0.01$ & $1.60^{\mathrm{b}} \pm 0.01$ & $1.59^{\mathrm{b}} \pm 0.02$ & $1.40^{\mathrm{c}} \pm 0.01$ & & & & \\
\hline
\end{tabular}

Same superscripts in different treatments groups and days of interval did not differ significantly ( $p>0.05)$ where as different superscripts in different treatment groups and days of interval differ significantly $(\mathrm{p}<0.05)$.

$\mathrm{T}_{0}=$ Control group, $\mathrm{T}_{1}=0.01 \%$ BHT (Beta hydroxyl toluene), $\mathrm{T}_{2}=0.5 \%$ Lemon extract, $\mathrm{T}_{3}=1 \%$ Lemon extract, DI=Days of Intervals,
Treat $=$
Treatment,
$\mathrm{T} * \mathrm{DI}=$ Interaction
of
Treatment
and
Days
of Intervals. 


\section{CONCLUSIONS}

It is revealed from the study that lemon extract added at $1 \%$ in chicken meatballs was better in terms of nutrition, sensory, physicochemical, anti-oxidative and microbial attributes. Therefore, $1 \%$ lemon extract can be added in chicken meatballs as a source of natural antioxidant.

\section{ACKNOWLEDGEMENTS}

The authors are highly grateful to the Department of Animal Science and technicians of Animal Science Laboratory for their continuous support to complete the research work.

\section{REFERENCES}

AOAC. (2005). Association of Official Analytical Chemists, Official method of analysis, $17^{\text {th }}$ ed. Washington D.C.

Babatunde, O.A. and Adewumi, A.O. (2015). Effects of ethanolic extract of garlic, roselle and ginger on quality attributes of chicken patties. African Journal of Biotechnology, 14(8):688-694.

Baker, I.A., Alkass, J.E. and Saleh, H.H. (2013). Reduction of oxidative rancidity and microbial activities of the karadi lamb patties in freezing storage using natural antioxidant extracts of rosemary and ginger. International Journal of Agricultural and Food Research, 2(1):31-42.

Banerjee, R., Verma, A.K., Das, A.K., Rajkumar, V., Shewalkar, A.A. and Narkhede, H.P. (2012). Antioxidant effects of broccoli powder extract in goat meat nuggets. Meat Science, 91(2):179-184.

Chidanandaiah Keshri, R.C. and Sanyal, M.K. (2009). Effect of sodium alginate coating with preservatives on the quality of meat patties during refrigerated storage. Journal of Muscle Foods, 20(3):275-292.

Contini, C., Katsikogianni, M.G.F.T., O’Neill, V., O'Sullivan, M., Boland, F., Dowling, D. P. and Monahan, F.J. (2014). Storage stability of an antioxidant active packaging coated with citrus extract following a plasma jet pretreatment. Food and Bioprocess Technology,7(8):2228-2240.

Das, A.K., Anjaneyulu, A.S.R., Gadeka,r Y.P., Singh, R.P. and Pragati, H. (2008). Effect of full-fat soy paste and textured soy granules on quality and shelflife of goat meat nuggets in frozen storage. Meat Science, 80(3):607-614.

Fasseas, M.K., Mountzouris, C.K., Tarantilis, P.A., Polissiou, M. and Zervas, G. (2007). Antioxidant activity in meat treated with oregano and sage essential oils. Food Chemistry, 106(3):1188-1194. 
Hayes, J.E., Allen, P., Brunton, N., O'Grady, M.N. and Kerry, J.P. (2011). Phenol composion of in-vitro antioxidant capacity of four commercial phytochemical products: olive leaf extracts (Oleaeuropaea L), lutein, sesame oil and ellagic acid. Food Chemistry, 126:948-955.

Irshad, A., Sharma, B.D., Ahmed, S.R., Talukder, S., Malav, O.P. and Kumar, A. (2016). Effect of incorporation of calcium lactate on physicochemical, textural, and sensory properties of restructured buffalo meat loaves. World Veterinary, 9(2):151-159.

Islam, F., Hossain, M.A., Rahman, M.F., Hashem, M.A., Rahman, M. and Azad, M.A.K. (2018). Effect of synthetic or herbal preservatives on the quality of beef meatballs at different shelf life periods. SAARC Journal of Agriculture, 16(1):23-34.

ISO (1995). Recommendation of the meeting of the subcommittee, International Organization for Standardization, on meat and meat products. ISO/TC36/SC-6. The Netherlands, 10-18.

Jama, N., Muchenje, V., Chimonyo, M., Strydom, P.E., Dzama, K. and Raats, J.G. (2008). Cooking loss components of beef from Nguni, Bonsmara and Angus steers. African Journal of Agricultural Research, 3(6):416-420.

Jung, S., Choe, J., Kim, B., Yun, H., Kruk, Z.A. and Jo, C. (2010). Effect of dietary mixture of gallic acid and linoleinic acid on anti-oxidative potential and quality of breast meat from broilers. Meat Science, 86(2):520-526.

Jahan, I., Haque, M.A., Hashem, M.A., Rima, F.J. Akhter, S. and Hossain, M.A. (2018). Formulation of value added beef meatballs with pomegranate (Punica granatum) extract as a source of natural antioxidant. Journal of Meat Science and Technology, 6(1):12-18.

Kouba, M., Enser, M., Whittington, F.M. and Nute, G.R. (2003). Effect of a high linoleinic acid diet on lipogenic enzyme activities, fatty acid composition and meat quality in the growing pig. Journal of Animal Science, 81(8):19671679.

Lahucky, R., Nuernberg, K., Kovac, L., Bucko, O. and Nuernberg, G. (2010). Assessment of the antioxidant potential of selected plant extracts in vitro and in vivo experiments on pork. Meat Science, 85(4):779-784.

Karimi, A., Mohammadi-Kamalabadi, M., Rafieian-Kopaei, M., Amjad, L. and Salimzadeh, L. (2016). Determination of antioxidant activity, phenolic contents and antivirol potential of methanol extract of Euphorbia spinidens Bornm (Euphorbiaceae). Tropical Journal of Pharmaceutical Research, 15(4):759-764.

Karre, L., Lopez, K. and Getty, K.J.K. (2013). Natural antioxidants in meat and poultry products. Meat Science, 94:220-227. 
Keskokoglu, H. and Uren, A. (2017). Inhibitory effects of grape seed extract on the formation of heterocyclic aromatic amines in beef and chicken meatballs cooked by different techniques. International Journal of Food Properties, 20(1), 2017.

Lund, M.N., Hviid, M.S. and Skibsted, L.H. (2007). The combined effect of antioxidants and modified atmosphere packaging on protein and lipid oxidation in beef patties during chill storage. Meat Science, 76:226-233.

Magdalena, G., Guzek, D., Najda, A., Brodowska, M., Górska-Horczyczak, E., Iwona Wojtasik-Kalinowska, I. and Godziszewska, J. (2017). Oxidative and microbial stability of poultry meatballs added with coriander extracts and packed in cold modified atmosphere. International Journal of Food Properties, 20(11):2527-2537.

Naveena, B.M., Sen, A.R., Vaithiyanathan, S., Babji, Y. and Kondaiah, N. (2008). Comparative efficacy of pomegranate juice, pomegranate rind powder extract and BHT as antioxidants in cooked chicken patties. Meat Science, 80(4):1304-1308.

Prabakaran, R. (2012). Overview of poultry production in India vis-à-vis global scenario proceeding of XXIX IPSACON, 1:3-20.

Prashad, W., Khamrui, K., Surajit, M. and Richa, B. (2017). Anti-oxidative, physico-chemical and sensory attributes of burfi affected by incorporation of different herbs and its comparison with synthetic anti-oxidant (BHA). Journal of Food Science Technology, 54(6):1-8.

Rubio, B., Martinej, B., Sanchez, M.J., Dolores, Garcia-Cachan. M.A., Rivira, J. and Jaime, I. (2006). Study of self-life of a dry fermented sausage Salchichon made from raw material enriched in monounsaturated and polyunsaturated fatty acids and stored under modified atmospheres. Meat Science, 76:128137.

Raja, W.H., Kumar, S., Bhat, Z.F. and Kumar, P. (2014). Effect of ambient storage on the quality characteristics of aerobically packaged fish curls incorporated with different flours. Springer Plus, 3(1):106.

Rima, F.J., Sadakuzzaman, M., Hossain, M.A., Ali, M.S. and Hashem, M.A. (2019). Effect of gamma irradiation on shelf life and quality of broiler meat. SAARC Journal of Agriculture, 17(1):149-159.

Reddy, D.M., Vani, S., Naveen, Z. and Eswara, R.B. (2017). Comparative effect of natural and synthetic antioxidants on microbiological quality of chicken meat patties during refrigeration storage. International Journal of Science, Environment and Technology, 6(1):443-448.

Saba, N.A., Hashem, M.A., Azad, M.A.K., Hossain, M.A. and Khan, M. (2018). Effect of bottle gourd leaf (Lagenaria siceraria) extract on the quality of beef meatball. Bangladesh Journal of Animal Science, 47(2):105-113. 
Singh, S. and Immanuel, G. (2014). Extraction of antioxidants from fruit peels and its utilization in paneer. Journal of Food Process Technology, 5:349.

Siddiqua, T., Hossain, M.A., Khan, M. and Hashem, M.A. (2018). Formulation of value added beef meatball using tulsi (Ocimum sanctum) leaf extract as a source of natural antioxidant. Journal of Bangladesh Agricultural University, 16(2):260-265.

Sharma, P., Jha, A.B., Dubey, R.S. and Pessarakli, M. (2012). Reactive oxygen species, oxidative damage and antioxidative defense mechanism in plants under stressful conditions. Journal of Botany, 1-26.

Syuhairah, A., Huda, N., Syahariza, Z.A. and Fazilah, A.(2016). Effects of vegetable incorporation on physical and sensory characteristics of sausages. Asian Journal of Poultry Science, 10:117-125.

Suradkar, U.S., Bumla, N.A., Maria, A., Zanjad, P.N. and Sofi, A.H. (2013). Effect of incorporation of bread crumbs on the physicochemical and sensory quality of chicken nuggets. International Journal of Food Nutrition and Safety, 3(1):1-6.

Verma, A.K., Rajkumar, V., Banerjee, R., Biswas, S. and Das, A.K. (2013). Guava (Psidium guajava $\mathrm{L}$.) powder as an antioxidant dietary fiber in sheep meat nuggets. Asian- Australasian Journal of Animal Science, 26(3):886-895.

Yadav, S., Pathera, A.K., Islam, R.U.I., Malik, A.K. and Sharma, D.P. (2018). Effect of wheat bran and dried carrot pomace addition on quality characteristics of chicken sausage. Asian-Australasian Journal of Animal Science, 31(5):729737.

Yu, L.H., Lee, E.S., Jeong, J.Y., Paik, H.D., Choi, J.H. and Kim, C.J. (2005). Effect of thawing temperature on the physicochemical properties of pre-rigor frozen chicken breast and leg muscles. Meat Science, 71(2):375-382.

Zargar, F.A., Kumar, S., Bhat, Z.F. and Kumar, P. (2017). Effect of incorporation of carrot on the quality characteristics of chicken sausages. Indian Journal of Poultry Science, 52(1):91-95.

Zargar, F.A., Kumar, S., Bhat, Z.F. and Kumar, P. (2014). Effect of pumpkin on the quality characteristics and storage quality of aerobically packaged chicken sausages. Springer Plus, 3:39. 